
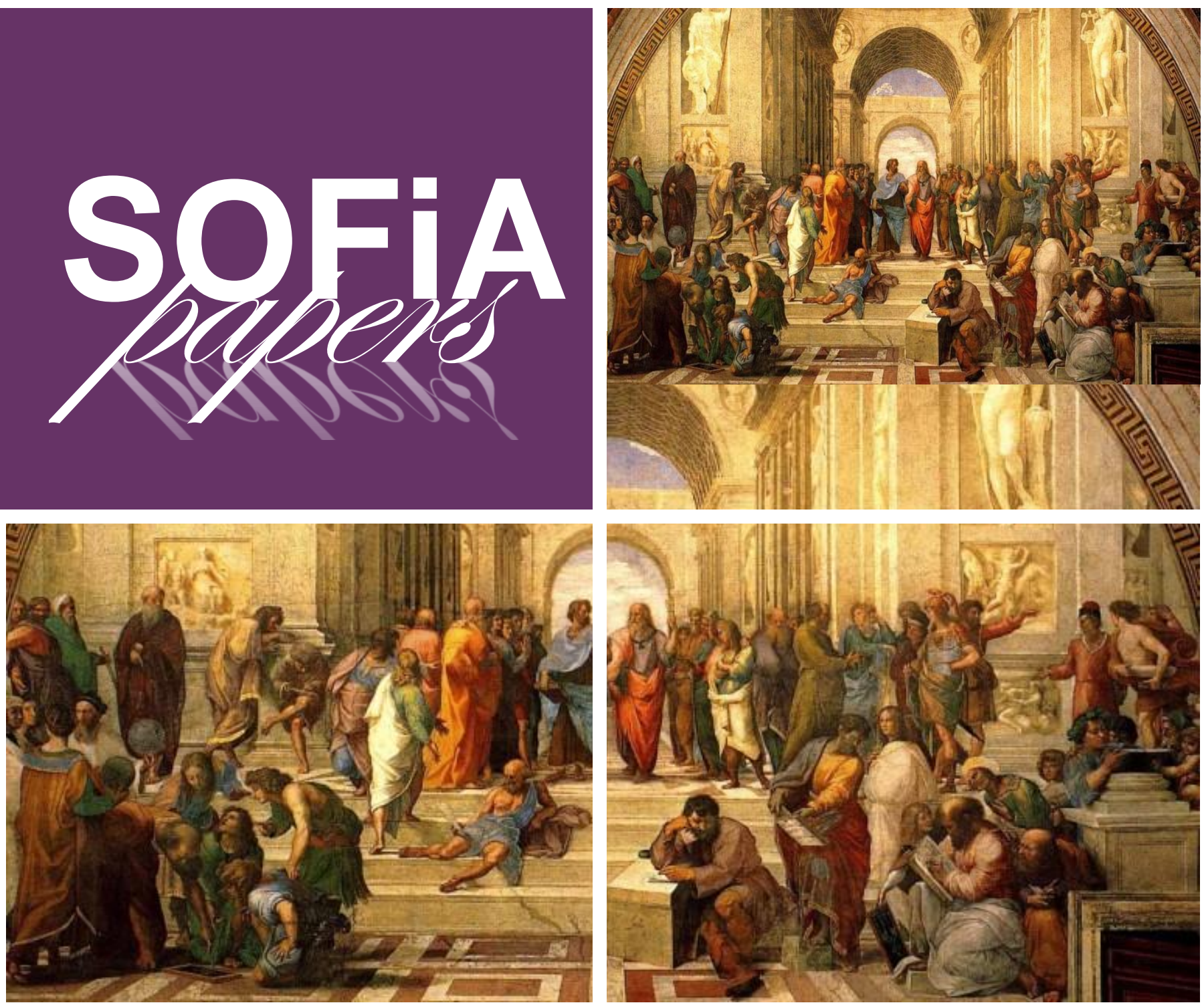

\title{
UNIFESP
}

Federal University of São Paulo

11th SOFIA's approved papers from presented researches 


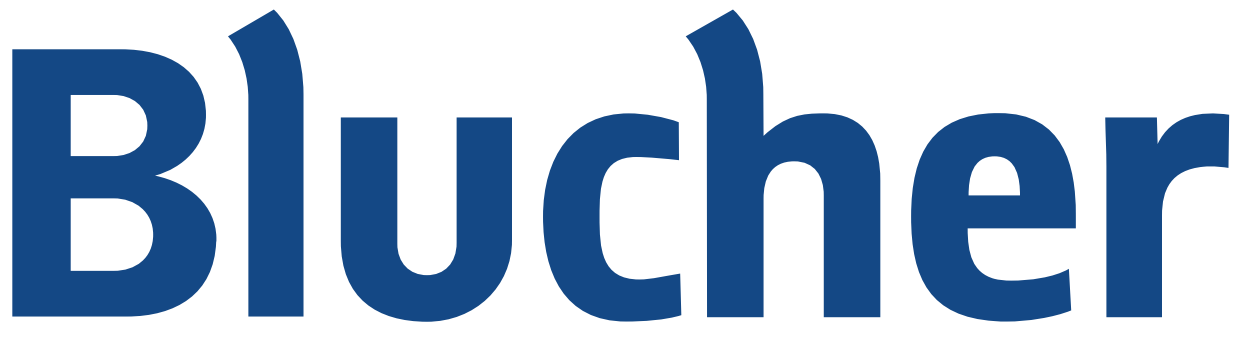

www.blucher.com.br 


\section{1th SOFiA}

\section{Symposium of Philosophical and Academic Advising Semana de Orientação Filosófica e Acadêmica}

2018 International Edition

sofia.unifesp.inscricao@gmail.com

SOFiA's Papers

ISSN: 2358-6567

Publisher: Blucher

\section{Congress chair:}

Juliana de Cassia Correia

\section{Head-editor:}

L. Hollanda

\section{Scientific Committee:}

Arlenice Almeida da Silva (Unifesp, Ph.D.) Cecilia Cintra Cavaleiro de Macedo (Unifesp, Ph.D.)

Eduardo H. P. Kickhöfel (Unifesp, Ph.D.) Francisco P. Machado (Unifesp, Ph.D.) Henry Burnett (Unifesp, Ph.D.)

\section{Editorial support:}

Peterson Novaes

Juraci da Silva

\section{Organizer committee:}

Antonio Pedrosa de Vasconcelos

Bruna Guimarães

Carolina Costa Calil

Dakla Souza Lima

Diogo Oliveira Dias

Diogo Gonzaga da Costa

Giovanni Corradi Sgai

Josefa Rouse da Silva

Julio César Silveira

Karoline Desireé Rodrigues

Lucas Maximiano
Izilda Johanson (Unifesp, Ph.D.)

Jamil Iskandar (Unifesp, Ph.D.)

Juvenal Savian Filho (Unifesp, Ph.D.)

Luciano Codato (Unifesp, Ph.D.)

Luciano Gatti (Unifesp, Ph.D.)

Olivia da Rocha Robba (USP/CNPq, Ph.D.)
Luciana de Paula Coelho

Marília Alcântara

Matheus Silva Espessoto

Paola Louise Ferreira de Rezende

Peterson Novaes

Sarah Morales Neumann

SiOmone Conceição dos Santos

Thamiris Tieko Obana

Vinícius Mendes da Silva

Wagner Ferraz 


\section{Invited Speakers:}

Ana Paula Correia (Centro de Defesa e Convivência da Mulher)

Brunno Almeida Maia (UNIFESP)

Daniela Olorruama (UNIFESP)

Flávio Antônio da Silva Nascimento (UFMT)

Frank Viana Carvalho (USP)

Jaqueline Conceição da Silva (Coletivo Di Jejê)

Luiz Fernando Fontes Teixeira (UNIFESP)

Rafael Rodrigues Garcia (UNICAMP)

\section{Attendees:}

- UNIFESP teaching staff:

Arlenice Almeida da Silva, Ph.D.

Cecilia Cintra Cavaleiro de Macedo, Ph.D.

Edson Teles, Ph.D.

Eduardo H. P. Kickhöfel, Ph.D.

Francisco P. Machado, Ph.D.

Izilda Johanson, Ph.D.

Jacira de Freitas, Ph.D.

Jamil Iskandar, Ph.D.

Julio Moracen, Ph.D.

Olgária Matos, Ph.D.

Silvio Rosa Filho, Ph.D.

- Artists and students:

Agnes Karoline (UNIFESP)

Beatriz Fernandes Pinheiro do Amaral (Arte-Educadora / UNIFESP)

Bia Doxum (Rapper e Compositora)

Carol Bolívia (Rapper e compositora)

Gabi Nyarai

Mc Tflow

Poeta Katrina

Viviane Jorge dos Santos (Grupo: Micropolítica e Yoga)

Warley Noua (cantor e compositor) 


\section{FOREKORD}

It is a great pleasure to present to you the selected papers from our $11^{\text {th }}$ SOFiA (Symposium of Philosophical and Academic Advising / Semana de Orientação Filosófica e Acadêmica), which took place at Federal University of São Paulo (UNIFESP) from 18 September 2017 to 22 September 2017.

Besides, it is important to add that participants' list was impressive, including many from some of the most influential and respected universities in the world. They came from Italy, Israel and Brazil. I was really looking forward to releasing this publication so that we all can appreciate their fist-rate works.

Furthermore, I do would like to thank directly Jonatas Eliakim (member of Blucher) and Juliana de Cassia Correia (the Chair of $11^{\text {th }}$ SOFIA), as well as all from organizer and scientific committees. Without their essential and exceptional support this edition could not be possible.

The present edition took considerably more time to be published than we expected for the sake of scarce resources available in Brazil to this kind of events. Thereby, it is important to highlight Blucher support, which carries on showing its commitment with the Education and science by sponsoring us.

Finally, the following is a list of honourable mentions to the outstanding works presented in the $11^{\text {th }}$ SOFiA, according to each of sessions' chair: 
- Diogo Alves da Conceição Santana (UERJ)

Ironia e Suspensão Teleológica do Geral em Soren Kierkegaard

- Fábio Rodrigues de Ávila (UNIFESP)

A etocracia de Holbach: política e moral numa perspectiva materialista

- Paola Louise Ferreira de Rezende (UNIFESP)

A questão de gênero em o Céu de Suely

- Quesidonis Felipe da Silva (USP)

Boa vontade, dever e respeito

L. Hollanda

The Head-Editor. 